\title{
Proteomic analysis of synaptic protein turnover in the anterior cingulate cortex after nerve injury
}

\author{
Hyoung-Gon Ko ${ }^{1,2 \dagger}$, Dong Ik Park ${ }^{3 \dagger}$, Ji Hyun Lee ${ }^{1}$, Christoph W. Turck ${ }^{3}$ and Bong-Kiun Kaang ${ }^{2 *}$
}

\begin{abstract}
Synaptic proteins play an important role for the regulation of synaptic plasticity. Numerous studies have identified and revealed individual synaptic protein functions using protein overexpression or deletion. In neuropathic pain nociceptive stimuli conveyed from the periphery repetitively stimulate neurons in the central nerve system, brain and spinal cord. Neuronal activities change the turnover (synthesis and degradation) rate of synaptic proteins. Thus, the analysis of synaptic protein turnover rather than just expression level change is critical for studying the role of synaptic proteins in synaptic plasticity. Here, we analyzed synaptosomal proteome in the anterior cingulate cortex (ACC) to identify protein turnover rate changes caused by peripheral nerve injury. Whereas PKCY levels were not altered, we found that the protein's turnover rate decreased after peripheral nerve injury. Our results suggest that postsynaptic PKCY synthesized by neuronal activities in the ACC is translocated to the postsynaptic membrane with an extended half-life.
\end{abstract}

\section{Main text}

External stimuli can change the efficacy of synaptic transmission, referred to as synaptic plasticity that underlies normal and pathophysiological brain functions including learning, emotion, cognition and pain. The study of synaptic protein function is critical for understanding how synaptic plasticity is regulated. The majority of studies on synaptic protein function have manipulated protein levels through deletion, reduction, and/or overexpression in cultured cells and/or animal models. In order to sustain synaptic function proteins have a finite life time that ranges from a few hours to months $[1,2]$ caused by continuous synthesis and degradation. Specific signals or stimuli can induce a change of synaptic protein turnover rate that contributes to synaptic plasticity [3-5].

Neuropathic pain is a disease known to be induced by abnormal signal intensification in parts of a pain signaling circuit such as spinal cord or supraspinal level without external injury. Many studies have shown that the anterior cingulate cortex $(\mathrm{ACC})$ plays a role in the affective mode of

\footnotetext{
* Correspondence: kaang@snu.ac.kr

${ }^{\dagger}$ Hyoung-Gon Ko and Dong Ik Park contributed equally to this work. ${ }^{2}$ Department of Biological Sciences, College of Natural Sciences, Seoul National University, 1 Gwanangno, Gwanak-gu, Seoul 08826, South Korea Full list of author information is available at the end of the article
}

pain including neuropathic pain [6, 7]. It is well known that in the ACC synaptic proteins contribute to the induction of neuropathic pain by regulating synaptic plasticity [8]. In previous study, we have analyzed turnover rate changes of synaptic proteins with a molecular weight greater than 90 $\mathrm{kDa}$ [9]. Using LC-MS analysis we found that NCAM1 has a rapid turnover in the ACC following peripheral nerve injury which plays an important role in long-term potentiation and neuropathic pain. In the current study, we have extended our investigation of a neuropathic pain mouse model to the turnover analysis of ACC synaptic proteins with a molecular weight smaller than $90 \mathrm{kDa}$.

To examine synaptic protein turnover rates we used a partial stable isotope metabolic labeling method (Fig. 1a). Briefly, 8 weeks old male mice were first fed with a ${ }^{14} \mathrm{~N}$ diet for 10 days for food pellet adaptation. Following ligation of the common peroneal nerve (CPN) with a wax coated braided suture the animals were switched to a ${ }^{15} \mathrm{~N}$ bacterial diet. After 7 days, mice were decapitated and the crude ACC synaptosomal P2 fraction was purified for LC-MS analysis. SDS polyacrylamide gel electrophoresis showed that approximately $70 \%$ of all synaptic proteins had a molecular weight of less than $90 \mathrm{kDa}$ with no significant expression level difference between sham and nerve injury group (Fig. 


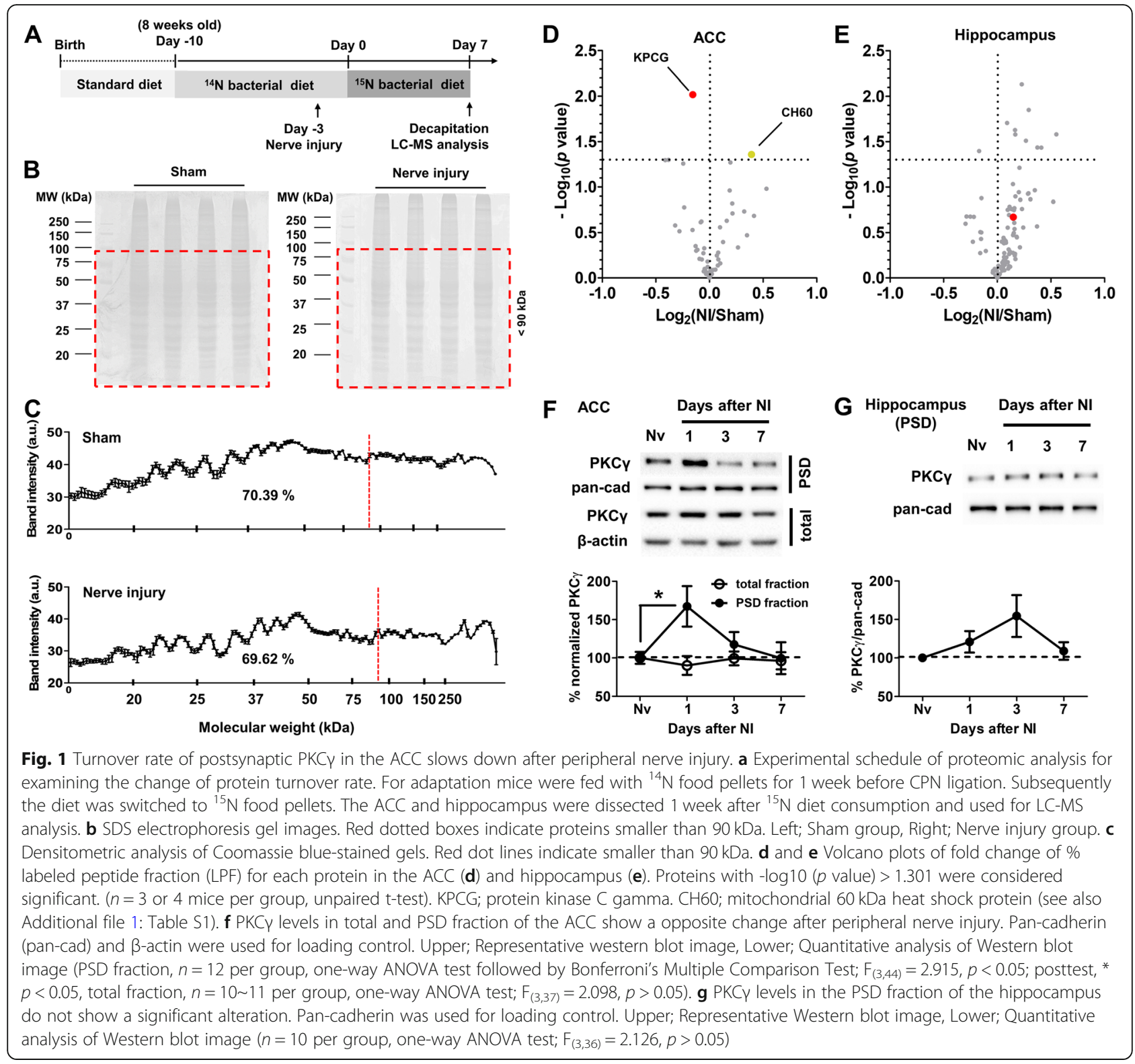

$1 \mathrm{~b}$ and c; Sham $=70.39 \pm 0.15 \%$, Nerve injury $=69.62 \pm$ $0.36 \%$, unpaired $\mathrm{t}$-test, $p>0.05$ ). We therefore decided to analyze turnover rather than expression level differences of these proteins induced by peripheral nerve injury. Following in-gel tryptic digestion and peptide extraction we calculated the ${ }^{15} \mathrm{~N}$-labeled peptide fraction (LPF) using the in-house developed ProTurnyzer software [10]. The NI/Sham LPF ratio of two ACC proteins, KPCG (protein kinase $\mathrm{C}$ gamma, $\mathrm{PKC} \gamma$ ) and $\mathrm{CH} 60$ (mitochondrial $60 \mathrm{kDa}$ heat shock protein, HSP60) indicated a significant turnover rate change following peripheral nerve injury (Fig. 1d and Additional file 1: Table S1; Sham vs. Nerve injury, unpaired t-test, $\mathrm{PKC} \gamma, p<$ 0.01 , HSP60, $p<0.05$ ). While CH60 has been shown to be one of the components in proteolytic machinery at synapse and thus may play a role in protein turnover regulation [11], mitochondrial contamination in the synaptosome preparation cannot be excluded. Therefore, our subsequent analysis focused on PKCY. When we analyzed the hippocampus, we did not observe any significant PKCY turnover change between sham and nerve injury groups (Fig. 1e, Sham vs. Nerve injury, unpaired t-test, PKC $\gamma, p>$ 0.05). This result shows a region-specific change of $\mathrm{PKC} \gamma$ turnover rate after peripheral nerve injury. We next examined $\mathrm{PKC} \gamma$ level changes in the ACC after peripheral nerve injury using Western blot. The ACC tissue was dissected from naïve and nerve injury-operated mice 1,3 or 7 days after surgery and PSD fraction prepared by sucrose gradient centrifugation. PKC $\gamma$ levels in PSD fraction of the ACC showed a significant change over time (Fig. 1f; one-way ANOVA followed by Bonferroni's Multiple Comparison 
Test; $\mathrm{F}_{(3,44)}=2.915, p<0.05$; posttest, $\left.{ }^{*} p<0.05\right)$ showing enhancement 1 day after nerve injury and then returning to basal level. However, total $\mathrm{PKC} \gamma$ showed no significant change over time. Also, no significant changes were found in PSD fraction of the hippocampus (Fig. 1g; one-way ANOVA test; $\left.\mathrm{F}_{(3,36)}=2.126, p>0.05\right)$.

In this study, we assessed the turnover rate of ACC synaptic proteins smaller than $90 \mathrm{kDa}$ and identified $\mathrm{PKC} \gamma$ that showed a smaller turnover rate after peripheral nerve injury. $\mathrm{The} \mathrm{PKC} \gamma$ isoform has the unique feature of neuron specific expression where it is localized in the soma, dendrite and axon. In the synapse, PKCY is exclusively located in the postsynaptic site (dendritic spine), but not in the presynaptic terminal $[12,13]$. Interestingly, $\mathrm{PKC} \gamma$ translocates between the cytoplasm and membrane depending on the specific stimulus $[14,15]$. These characteristics suggest that $\mathrm{PKC} Y$ is involved in synaptic plasticity. In fact, a previous study using $\mathrm{PKCY}$ knock out (KO) mice reported that $\mathrm{PKCY}$ is required for LTP in the hippocampus [16]. Also, it is well known that in the ACC LTP is involved in the cellular mechanism of neuropathic pain. Our results show that synaptic $\mathrm{PKC} Y$ levels in the ACC quickly increase and subsequently return to basal levels by slowing down its turnover rate after peripheral nerve injury. Since total PKC $\gamma$ levels did not change, these results imply that PKCY may be involved in the formation of neuropathic pain by translocating rapidly to the specific postsynaptic membrane activated by neuronal stimuli induced by peripheral nerve injury, but gradually reduced in postsynapse which is not associated with pain processing. In addition, translocated synaptic $\mathrm{PKC} \gamma$ may perform stable functions in the synaptic region with extended half-life.

The present study is the first one that examines the brain region-specific role of $\mathrm{PKC} \gamma$ in neuropathic pain. $\mathrm{PKC}$-deficient mice show a diminished neuropathic pain phenotype after peripheral nerve injury [17]. In the spinal cord, $\mathrm{PKC} \gamma$ interneurons receive $\mathrm{A} \beta$ afferent input and contribute to the transformation of tactile to nociceptive information as an excitatory interneuron [18]. While multiple studies have investigated the role of spinal PKC $\gamma$, the protein has been rarely studied in relation to neuropathic pain in other brain regions. Future brain region-specific $\mathrm{PKC} \gamma$ deletion or knockdown mice will help to further elucidate the novel role of $\mathrm{PKC} \gamma$ in neuropathic pain.

\section{Supplementary information}

Supplementary information accompanies this paper at https://doi.org/10. 1186/s13041-020-0564-y.

Additional file 1: Table S1. The LPF profiles of synaptic proteins smaller than $90 \mathrm{kDa}$ in the ACC and hippocampus of the sham and nerve-injured mice. Red indicates $p<0.05$ in unpaired t-test. The hippocampal P2 fraction was examined as a negative control.

\section{Authors' contributions}

HGK designed the studies, carried out the molecular experiments, outlined the manuscript and wrote the manuscript. JHL performed western blot analysis. DIP performed quantitative protein turnover analysis. CWT and BKK supervised the experiments, participated in the interpretation of the data, and wrote the manuscript. All authors read and approved the final manuscript

\section{Funding}

This work was supported by two National Research Foundation (NRF) of Korea grants funded by the Korean government (MSIP) [NRF-

2012R1A3A1050385 to BKK and 2018R1C1B6008530 to HGK] and the Max Planck Society to CWT and DIP.

\section{Availability of data and materials}

All data analyzed in this study were included in this article. The detailed material and method information is presented in our previous study [9].

\section{Ethics approval}

All the experiments were approved by the Institute of Laboratory Animal Resources of Seoul National University (SNU-150911-5-1).

\section{Consent for publication}

Not applicable.

\section{Competing interests}

The authors declare that they have no competing interests.

\section{Author details}

1'Department of Anatomy and Neurobiology, School of Dentistry, Kyungpook National University, 2177 Dalgubeol-daero, Daegu 41940, South Korea. ${ }^{2}$ Department of Biological Sciences, College of Natural Sciences, Seoul National University, 1 Gwanangno, Gwanak-gu, Seoul 08826, South Korea. ${ }^{3}$ Department of Translational Research in Psychiatry, Max Planck Institute of Psychiatry, Kraepelinstr. 2, D-80804 Munich, Germany.

Received: 5 November 2019 Accepted: 3 February 2020

Published online: 12 February 2020

\section{References}

1. Li KW, Hornshaw MP, Van Der Schors RC, Watson R, Tate S, Casetta B, et al. Proteomics analysis of rat brain postsynaptic density. Implications of the diverse protein functional groups for the integration of synaptic physiology. J Biol Chem. 2004;279(2):987-1002.

2. Peng J, Kim MJ, Cheng D, Duong DM, Gygi SP, Sheng M. Semiquantitative proteomic analysis of rat forebrain postsynaptic density fractions by mass spectrometry. J Biol Chem. 2004;279(20):21003-11.

3. Alvarez-Castelao B, Schuman EM. The regulation of synaptic protein turnover. J Biol Chem. 2015;290(48):28623-30.

4. Choi JH, Kim JE, Kaang BK. Protein synthesis and degradation are required for the incorporation of modified information into the pre-existing objectlocation memory. Mol Brain. 2010;3:1

5. Kaang BK, Lee $\mathrm{SH}$, Kim H. Synaptic protein degradation as a mechanism in memory reorganization. Neuroscientist. 2009:15(5):430-5.

6. Bliss TV, Collingridge GL, Kaang BK, Zhuo M. Synaptic plasticity in the anterior cingulate cortex in acute and chronic pain. Nat Rev Neurosci. 2016; 17(8):485-96.

7. Kang SJ, Kwak C, Lee J, Sim SE, Shim J, Choi T, et al. Bidirectional modulation of hyperalgesia via the specific control of excitatory and inhibitory neuronal activity in the ACC. Mol Brain. 2015;8(1):81.

8. Zhuo M. Plasticity of NMDA receptor NR2B subunit in memory and chronic pain. Mol Brain. 2009;2:4

9. Ko HG, Choi JH, Park DI, Kang SJ, Lim CS, Sim SE, et al. Rapid turnover of cortical NCAM1 regulates synaptic reorganization after peripheral nerve injury. Cell Rep. 2018;22(3):748-59.

10. Zhang Y, Reckow S, Webhofer C, Boehme M, Gormanns P, Egge-Jacobsen WM, et al. Proteome scale turnover analysis in live animals using stable isotope metabolic labeling. Anal Chem. 2011;83(5):1665-72.

11. Gorenberg EL, Chandra SS. The role of co-chaperones in synaptic Proteostasis and neurodegenerative disease. Front Neurosci. 2017;11:248. 
12. Kose A, Ito A, Saito N, Tanaka C. Electron microscopic localization of gamma- and beta Il-subspecies of protein kinase $\mathrm{C}$ in rat hippocampus. Brain Res. 1990;518(1-2):209-17.

13. Saito $N$, Shirai Y. Protein kinase $C$ gamma (PKC gamma): function of neuron specific isotype. J Biochem. 2002;132(5):683-7.

14. Narita M, Mizoguchi H, Narita M, Nagase H, Suzuki T, Tseng LF. Involvement of spinal protein kinase Cgamma in the attenuation of opioid mu-receptormediated G-protein activation after chronic intrathecal administration of [DAla2,N-MePhe4,Gly-OI(5)]enkephalin. J Neurosci. 2001;21(11):3715-20.

15. Narita M, Aoki T, Ozaki S, Yajima Y, Suzuki T. Involvement of protein kinase Cgamma isoform in morphine-induced reinforcing effects. Neuroscience. 2001;103(2):309-14.

16. Abeliovich A, Chen C, Goda Y, Silva AJ, Stevens CF, Tonegawa S. Modified hippocampal long-term potentiation in PKC gamma-mutant mice. Cell. 1993;75(7):1253-62.

17. Malmberg AB, Chen C, Tonegawa S, Basbaum Al. Preserved acute pain and reduced neuropathic pain in mice lacking PKCgamma. Science. 1997; 278(5336):279-83.

18. Miraucourt LS, Dallel R, Voisin DL. Glycine inhibitory dysfunction turns touch into pain through PKCgamma interneurons. PLoS One. 2007;2(11):e1116.

\section{Publisher's Note}

Springer Nature remains neutral with regard to jurisdictional claims in published maps and institutional affiliations.

Ready to submit your research? Choose BMC and benefit from:

- fast, convenient online submission

- thorough peer review by experienced researchers in your field

- rapid publication on acceptance

- support for research data, including large and complex data types

- gold Open Access which fosters wider collaboration and increased citations

- maximum visibility for your research: over $100 \mathrm{M}$ website views per year

At BMC, research is always in progress.

Learn more biomedcentral.com/submissions 